\title{
References:
}

1. Voroshilov A.N. (2007) Sovremennyye organizatsionno-pravovyye formy kazach’yego samoupravleniya na Donu [Modern organizational and legal forms of Cossack self-government on the Don] : diss. kand. yurid. nauk. Rostov-na-Donu, 2007. 197 s. [in Russian].

2. Mishyna N.V. (2020) Orhany samoorhanizatsiyi naselennya v Ukrayini: typolohiya ta klasyfikatsiya [Bodies of selforganization of the population in Ukraine: typology and classification]. Naukovi pratsi Natsional'noho universytetu "Odes'ka yurydychna akademiya”. Vol. XXVI. Odesa. P. 81-89 [in Ukainian].

3. Mishyna N.V. (2014) Suchasni protsesy detsentralizatsiyi vykonavchoyi vlady ta reformuvannya mistsevoho samovryaduvannya $\mathrm{v}$ Ukrayini [Modern processes of decentralization of executive power and reform of local selfgovernment in Ukraine]. Naukovi pratsi Natsional'noho universytetu “Odes 'ka yurydychna akademiya”. Vol. 14. P. 228-233 [in Ukainian].

4. Mishyna N.V. (2002) Munitsipal'noye upravleniye v SSHA i v Soyedinennom Korolevstve Velikobritanii i Severnoy Irlandii: sravnitel'no-pravovoye issledovaniye [Municipal governance in the USA and the United Kingdom of Great Britain and Northern Ireland: comparative legal research] : dis. kand. yur. nauk. Odesa, 2002. 226 s. [in Russian].

5. Mishyna N.V. (2015) Doctrine of separation of powers at the local government level: the Ukrainian experience. Molodyy vchenyy. № 12.1. P. 97-101 [in English].

6. Cherkasov A.I. (2012) Regional'nyye i munitsipal'nyye sovety v mekhanizme mestnogo upravleniya zarubezhnykh stran $\mathrm{xRegional}$ and municipal councils in the mechanism of local government in foreign countriesъ. Proceedings of the Institute of State and Law of the Russian Academy of Sciences. № 1. S. 185-209 [in Russian].

7. Cherkasov A.I. (2016) Nekotoryye osobennosti upravleniya v sel'skoy mestnosti SSHA [Some features of management in the US countryside. Proceedings of the Institute of State and Law of the Russian Academy of Sciences]. № 6. S. 205-215 [in Russian].

\section{DOI https://doi.org/10.51647/kelm.2020.5.1.38}

\section{TYPOWE SYTUACJE DOCHODZENIOWE POCZATTKOWEGO ETAPU DOCHODZENIA WNIOSKU, OBIETNICY LUB NIESTOSOWNEJ KORZYŚCI}

\author{
Hennadii Honcharuk \\ student Katedry Dyscyplin Karno-Prawnych \\ Charkowskiego Narodowego Uniwersytetu Spraw Wewnętrznych (Charków, Ukraina)
}

ORCID ID: 0000-0002-7979-0855

Honcharuk@gmail.com

\begin{abstract}
Adnotacja. Artykuł poświęcony jest określeniu typowych sytuacji dochodzeniowych początkowego etapu dochodzenia propozycji, obietnicy lub niestosownej korzyści, czyli przestępstw przewidzianych w art. 369 Kodeksu Karnego Ukrainy. Ustalono, że zaletą prowadzenia dochodzenia przez grupę śledczych jest możliwość jednoczesnego prowadzenia kilku czynności dochodzeniowych (poszukiwawczych). Wadą dochodzenia grupowego są koszty organizacyjne - potrzeba gęstego planowania, harmonizacji i standaryzacji podejść i wyników, podziału pracy oraz wiekssze prawdopodobieństwo wycieku informacji. Należy również zauważyć,że podczas wykonywania przez pracowników jednostek operacyjnych zadań śledczego, korzystają z uprawnień śledczego. Stwierdzono, że zadaniem początkowego etapu dochodzenia przedprocesowego jest szybkie zebranie informacji niezbędnych i wystarczających do uznania konkretnej osoby za winną popełnienia zarzucanego przestępstwa oraz rzetelne jego utrwalenie procesowe. Sytuacje śledcze na początkowym etapie dochodzenia przedprocesowego są dodatkami kombinacji organizacyjnych, kryminalistycznych, procesowych, psychologicznych cech, stanów, działań i interakcji nad sytuacjami kryminalistycznymi i dochodzeniowymi rozpoczęcia postępowania karnego. Sytuacje dochodzeniowe początkowego etapu dochodzenia propozycji, obietnicy lub niestosownej korzyści powinny uwzględniać następujące cechy - stosunek w czasie zgłoszenia przestępstwa do faktu wykonania obiektywnej strony przestępstwa, opis przedmiotu przestępstwa, figurant postępowania, cechy organizacyjne i interakcje wewnątrz przedmiotu dochodzenia.
\end{abstract}

Słowa kluczowe: postępowanie karne, etap dochodzenia, sytuacja śledcza, algorytm, korupcja.

\section{TYPICAL INVESTIGATIVE SITUATIONS OF THE INITIAL STAGE OF INVESTIGATION OF A PROPOSAL, PROMISE OR PROVISION OF UNDUE PROFIT}

\author{
Hennadii Honcharuk \\ Applicant at the Department of Criminal Law Disciplines \\ Kharkiv National University of Internal Affairs (Kharkiv, Ukraine) \\ ORCID ID: 0000-0002-7979-0855 \\ Honcharuk@gmail.com
}

\begin{abstract}
The article is devoted to the identification of typical investigative situations of the initial stage of the investigation of a proposal, a promise or the provision of undue benefits, that is crimes provided for
\end{abstract}


in Art. 369 of the Criminal Code of Ukraine. It is determined that the advantage of conducting an investigation by a group of investigators is the possibility of simultaneously conducting several investigative (search) actions. The disadvantage of group investigation is organizational costs - the need for tight planning, harmonization and standardization of approaches and results, division of labor, as well as a higher probability of information leakage. It should also be noted that when the staff of operational units perform the instructions of the investigator, they use the powers of the investigator.

It is concluded that the task of the initial stage of the pre-trial investigation is the fastest collection of information necessary and sufficient to convict a particular person of committing the incriminated crime and its reliable procedural consolidation. Investigative situations of the initial stage of pre-trial investigation are superstructures of combinations of organizational, forensic, procedural, psychological features, states, actions and interactions over forensic and investigative situations of the beginning of criminal proceedings. Investigative situations of the initial stage of pre-trial investigation of the proposal, promise or provision of improper benefit should take into account the following characteristics - the ratio of time of notification of the crime and the fact of the objective side of the crime, description of the subject of the crime, organizational features and interactions.

Key words: criminal proceedings, investigation stage, investigative situation, algorithm, corruption.

\title{
ТИПОВІ СЛІДЧІ СИТУАЦІЇ ПОЧАТКОВОГО ЕТАПУ РОЗСЛІДУВАННЯ ПРОПОЗИЦЇ̈, ОБІЦЯНКИ АБО НАДАННЯ НЕПРАВОМІРНОЇ ВИГОДИ
}

\author{
Геннадій Гончарук \\ здобувач кафедри кримінально-правових дисциплін \\ Харківського національного університету внутрішніх справ (Харків, Украӥна) \\ ORCID ID: 0000-0002-7979-0855 \\ Honcharuk@gmail.com
}

Анотація. Стаття присвячена виявленню типових слідчих ситуацій початкового етапу розслідування пропозиції, обіцянки або надання неправомірної вигоди, тобто злочинів, передбачених ст. 369 КК України. Визначено, що перевагою здійснення розслідування групою слідчих є можливість одночасного проведення кількох слідчих (розшукових) дій. Недоліком групового розслідування є організаційні видатки - необхідність щільного планування, узгодження та стандартизації підходів і результатів, розподілу праці, а також більш висока ймовірність витоку інформації. Необхідно зазначити, що при виконанні співробітниками оперативних підрозділів доручень слідчого вони користуються повноваженнями слідчого.

Зроблено висновок, що завдання початкового етапу досудового розслідування - найшвидше збирання інформації, необхідної та достатньої для визнання конкретної особи винною у вчиненні інкримінованого злочину та надійне iї процесуальне закріплення. Слідчі ситуації початкового етапу досудового розслідування є надбудовами комбінацій організаційних, криміналістичних, процесуальних, психологічних ознак, станів, дій і взаємодій над криміналістичними та слідчими ситуаціями початку кримінального провадження. Слідчі ситуації початкового етапу досудового розслідування пропозиції, обіцянки або надання неправомірної вигоди мають враховувати такі характеристики: співвідношення у часі повідомлення про злочин і факту виконання об'єктивної сторони злочину, опис предмету злочину, фігурант провадження, організаційні ознаки та взаємодії всередині суб'єкту розслідування.

Ключові слова: кримінальне провадження, стадія розслідування, слідча ситуація, алгоритм, корупція.

Вступ. Актуальність звернення до питань етапізації кримінального провадження та алгоритмізації дій суб'єктів розслідування є очевидною у процесі розробки методології розслідувань певного виду злочинів. Також визначальною є необхідність щільного орієнтування розслідувань пропозиції, обіцянки або надання неправомірної вигоди, тобто злочинів, передбачених ст. 369 «Пропозиція, обіцянка або надання неправомірної вигоди службовій особі» Кримінального кодексу України (далі - КК) для вирішення завдань кримінального провадження, визначених ст. 2 Кримінального процесуального кодексу України (далі - КПК).

Завданням публікації є окреслення поля можливих слідчих ситуацій початкового етапу розслідування пропозиції, обіцянки або надання неправомірної вигоди та відповідних ним алгоритмів дій слідчого.

Об'єктом дослідження є діяльність із розслідування пропозиції, обіцянки або надання неправомірної вигоди. Предметом дослідження виступають нормативно-правові акти, наукові, навчальні та методичні джерела.

Основна частина. У криміналістичній науковій літературі розроблені теоретичні положення щодо проблематики етапізації кримінального провадження. Так, відома точка зору І.М. Лузгіна, який пропонує під «етапом розслідування» розуміти такий елемент розслідування, який є взаємозалежною системою дій, об'єднаних спільністю (єдністю) завдань, умовами розслідування, специфікою криміналістичних прийомів (Luzgin, 1973: 86). А.П. Шеремет зазначає, що кожний із етапів має певну специфіку щодо обсягу і методів криміналістичної діяльності (Sheremet, 2009: 337).

С.Ю. Косарєв вважає, що етап розслідування - це та його частина, якій властива наявність системи взаємопов'язаних і взаємозумовлених слідчих чи інших дій та заходів, а також тактичних операцій, поєднаних необхідністю вирішення відповідних завдань розслідування, умовами останнього та специфікою криміналістичних прийомів (Kosarev, 2008: 306). На думку А.Ф. Волобуєва, етап розслідування $є$ певним проміжним пунктом у процесі розслідування злочину, що характеризує стан слідства 3 метою визначення повноти вирішення його завдань і визначається прийнятими процесуальними рішеннями 3 кримінальної справи (Volobuiev, 2002: 14). 
Отже, методологічні розробки фахівців-криміналістів орієнтують на єдність завдань та умов розслідування як критерій для розмежування етапів кримінального провадження.

Відповідно до ст. 2 КПК завданнями кримінального провадження $є$ захист особи, суспільства та держави від кримінальних правопорушень, охорона прав, свобод та законних інтересів учасників кримінального провадження, а також забезпечення швидкого, повного та неупередженого розслідування і судового розгляду для того, щоб кожен, хто вчинив кримінальне правопорушення, був притягнутий до відповідальності в міру своєї вини, жоден невинуватий не був обвинувачений або засуджений, жодна особа не була піддана необгрунтованому процесуальному примусу і щоб до кожного учасника кримінального провадження була застосована належна правова процедура.

Вивчення цих критеріїв дає змогу констатувати, що їх дотримання можливе лише за умови високоефективного ведення діяльності із розслідування злочинів, а також те, що іманентною ознакою такої діяльності $€$ часова обмеженість. Одним із засобів підвищення ефективності діяльності із розслідування злочинів є типізація слідчих ситуацій та алгоритмізації дій суб'єктів розслідування. Встановлення типових слідчих ситуацій початкового етапу розслідування та відповідних ним алгоритмів дій слідчого насамперед потребує виявлення завдань початкового етапу розслідування.

Як зазначають В.Ю. Шепітько та Г.К. Авдєєва, метою алгоритмізації слідчої діяльності є іï оптимізація, підвищення ефективності, об’єктивності отриманих результатів, скорочення термінів розслідування та створення реальних передумов для розробки автоматизованих систем обробки та оцінки отриманої інформації, прийняття рішень у певних типових ситуаціях (Avdeeva, 2008).

Спеціальна література містить докладні переліки завдань початкового етапу розслідування. На думку Г.В. Москаленка, завданнями початкового етапу розслідування є:

1. 3'ясування і оцінка сформованої після порушення кримінальної справи слідчої ситуації, після чого відбувається висування версій, постановка тактичних завдань і вироблення засобів їхньої перевірки і вирішення.

2. Виявлення джерел інформації про розслідуваний злочин (матеріальні сліди, знаряддя злочину, свідкиочевидці).

3. Визначення напряму розслідування і розробка плану розслідування. У процесі розробки плану розслідування необхідно враховувати не лише типові риси конкретного випадку розслідування, але і виявляти його специфічні ознаки, що вимагають постановки спеціальних завдань і розробки версій індивідуального характеру.

4. Обрання форми і методів взаємодії з органами і службами, що здійснюють оперативно-розшукову роботу.

5. Пошук і одержання інформації про механізм і обстановку вчиненого злочину.

6. Збирання і вивчення відомостей про особистість потерпілого (спосіб життя, заняття, зв'язки, зміст дозвілля, захоплення, риси характеру, його поведінка до, у момент і після вчинення злочину).

7. Пошук, одержання та аналіз інформації про осіб, які вчинили злочин, їх розшук і затримання (Tishchenko, 2007: 377).

На думку В.В. Тіщенка, доцільним є такий перелік завдань початкового етапу розслідування злочинів:

1. Виявлення і фіксація доказової інформації щодо злочину, який розслідується по «гарячих слідах».

2. Вжиття заходів для запобігання втраті доказової інформації, що міститься у слідах, документах, інших об’єктах, іiі своєчасне виявлення та фіксація.

3. 3’ясування та оцінка сформованої після порушення кримінальної справи слідчої ситуації.

4. Виявлення джерел інформації про розслідуваний злочин.

5. Визначення напряму розслідування і розробка плану розслідування.

6. Обрання форми і методів взаємодії з органами і службами, що здійснюють оперативно-розшукову роботу

7. Пошук і одержання інформації про механізм і обстановку вчиненого злочину.

8. Збирання і вивчення відомостей про особистість потерпілого.

9. Пошук, одержання й аналіз інформації про осіб, які вчинили злочин, їх розшук і затримання (Tishchenko, 2007: 137).

Не дивлячись на безперечне теоретичне значення цих методичних розробок, необхідно визнати, що у них присутнє дещо еклектичне поєднання вказівок і на етапні завдання, і на послідовності операцій чи тактичних комбінацій, і на критерії якісності розслідування.

3 огляду на аксіоматичне знання про доцільність розбиття складного для пізнання об'єкту на окремі складники в рамках методичного комплексу початкового етапу досудового розслідування пропонується розглядати окремо:

- завдання, оскільки конкретизоване завдання завдає єдину мету для слідчих алгоритмів;

- слідчі ситуації, оскільки докладно вивчені слідчі ситуації залишають невелике поле для можливих криміналістично-тактичних комплексів (наборів із операцій і зі слідчих дій);

- слідчі алгоритми.

Завдання початкового етапу досудового розслідування - найшвидше збирання інформації, необхідної та достатньої для визнання конкретної особи винною у вчиненні інкримінованого злочину та надійне ії процесуальне закріплення. Слідчі ситуації початкового етапу досудового розслідування є надбудовами комбінацій організаційних, криміналістичних, процесуальних, психологічних ознак, станів, дій і взаємодій над криміналістичними та слідчими ситуаціями початку кримінального провадження. 
Насамперед необхідно розглянути криміналістичні складники слідчих ситуацій. Для розслідування такого виду злочинів, як надання, пропозиція чи обіцянка неправомірної вигоди, визначальним моментом є сnіввідношення у часі повідомлення про злочин і факту виконання об'єктивної сторони злочину:

I - ситуації, коли повідомлення передує факту надання, пропозиції чи обіцянки неправомірної вигоди (відносно більш сприятливі);

II - ситуації, коли повідомлення містить інформацію про діяння, які вже відбулися (відносно менш сприятливі).

Ситуації типу I (коли повідомлення передує факту надання, пропозиції чи обіцянки неправомірної вигоди) означають необхідність підготовки та проведення тактичного комплексу із гласних і негласних слідчих (розшукових) дій, зокрема:

- допит свідків (ст. 224 КПК);

- контроль за вчиненням злочину (ст. 271 КПК);

- обшук (ст. 234 КПК).

Також необхідними для гарантування реалізації завдання початкового етапу досудового розслідування є включення до криміналістично-тактичного комплексу таких заходів:

- використання конфіденційного співробітництва (ст. 275 КПК). Додатково, з огляду на посилення доказової сили сторони обвинувачення та з урахуванням можливостей доцільно здійснити такі заходи:

- аудіо-, відеоконтроль за особою (ст. 260 КПК);

- огляд і виїмка кореспонденції (ст. 262 КПК);

- зняття інформації із транспортних телекомунікаційних мереж (ст. 263 КПК);

- зняття інформації із електронних інформаційних систем (ст. 264 КПК);

- фіксація та збереження інформації, отриманої з телекомунікаційних мереж за допомогою технічних засобів і в результаті зняття відомостей із електронних інформаційних систем (ст. 265 КПК);

- обстеження публічно недоступних місць, житла чи іншого володіння особи (ст. 267 КПК);

- спостереження за особою, річчю або місцем (ст. 269 КПК);

- моніторинг банківських рахунків (ст. 269-1 КПК);

- огляд (ст. 237 КПК).

У ситуаціях типу І завдання початкового етапу розслідування реалізується шляхом затримання особи на місці вчинення кримінального правопорушення чи безпосередньо після його вчинення (п. 1) ч. 1 ст. 276 КПК «Випадки повідомлення про підозру». Ситуації типу II (коли повідомлення містить інформацію про діяння, які вже відбулися) є більш звичними для розслідування, яке за умовчанням має ретроспективний характер і є підставою для застосування стандартних криміналістичних методик.

Важливим криміналістичним моментом є опис предмету злочину:

А) предмет злочину вилучено, описано, немає обгрунтованих сумнівів у доказовій силі відповідних слідчих актів (відносно сприятлива ситуація);

Б) предмет злочину виявити, чи вилучити, чи зберегти не вдалося, можуть бути сумніви в доказовості (відносно не сприятлива ситуація);

В) предмет злочину був «віртуальний» (у разі вчинення пропозиції чи обіцянки щодо віддаленої передачі предмету злочину або обману) (відносно не сприятлива ситуація).

У ситуаціях типу «А» для вирішення завдання початкового етапу здебільшого достатнім є проведення процедури легалізації відомостей про предмет злочину шляхом:

- огляду (ст. 237 КПК), якщо раніше він не проводився;

- пред'явлення речей для впізнання (ст. 229 КПК).

У ситуаціях типу «Б» для вирішення завдання із розслідування необхідно компенсувати відсутність доказової сили в частині предмету злочину через виявлення додаткової інформації. Насамперед це щільне 3'ясування в очевидців обставин зникнення (псування) предмету злочину. Необхідне щільне дослідження місця вчинення злочину з метою виявлення предметів, які можуть мати слід від взаємодії з предметом злочину, у тому числі мікрочастки та запахи. Ключовим прийомом може стати використання конфіденційного співробітництва (ст. 275 КПК).

Особливістю ситуацій типу «В» $е$ «віртуальність» предмету злочину, його суто інформаційний, а не речовий характер. Тому для посилення переконливості позиції обвинувачення необхідно збільшувати «матеріалізацію» предмету злочину, що можливо шляхом збільшення непрямих доказів. Для цього фігуранта (фігурантів) слід залучати до спілкування щодо предмету злочину, його характеру, розміру, очікуваного надання iз фіксацією такого спілкування технічними засобами із подальшою легалізацією.

Важливою криміналістично-психологічною ознакою для встановлення слідчої обстановки є фігурант провадження, для формалізації чого пропонується розрізняти:

а) фігурант відомий, місце його знаходження відоме, наміру його змінити він не має, щиросердно розкаюється, активно співпрацює зі слідством (відносно сприятлива ситуація);

б) фігурант відомий, місце його знаходження відоме, наміру його змінити він не має, каяття не виявляє, мінімальна співпраця зі слідством чи виявляє невеликий супротив (нейтральна ситуація);

в) фігурант відомий, вину він заперечує, до слідства налаштований агресивно, місце його знаходження відоме (відносно не сприятлива ситуація);

г) особа, яку можливо обгрунтовано підозрювати у вчиненні злочину, невідома (нейтральна ситуація).

Взаємодія слідчого та фігуранта здійсняється за стандартними криміналістичними методиками. За організаційною ознакою для визначення алгоритму дій слідчого доцільно розрізняти ситуації, коли: 
1) слідство здійснюється одноособово;

2) слідство здійснюється групою осіб.

Перевагою здійснення розслідування групою слідчих є можливість одночасного проведення кількох слідчих (розшукових) дій. Недоліком групового розслідування є організаційні видатки - необхідність щільного планування, узгодження та стандартизації підходів і результатів, розподілу праці, а також більш висока ймовірність витоку інформації. При виконанні співробітниками оперативних підрозділів доручень слідчого вони користуються повноваженнями слідчого.

Важливим психологічно-організаційним моментом для визначення алгоритму дій слідчого є тип взаємодії всередині суб'єкту розслідування (слідчо-прокурорська взаємодія):

1) прокурор обмежується затвердженням слідчих актів;

2) прокурор здійснює щільне керівництво досудовим розслідуванням.

У тих випадках, коли прокурор, здійснюючи процесуальне керівництво, фактично перебирає на себе керівництво ходом розслідування, слідчий має більше часу та уваги приділяти спілкуванню із прокурором, а також бути готовим до виконання не завжди раціональних вказівок.

Таким чином, комбінації із визначених вище можливих станів AaIAa1)1) - СсІІВг2)2) утворюють поле для можливих слідчих ситуацій і визначають доцільні, з огляду на заявлену мету початкового етапу розслідування, алгоритми слідчих дій.

Висновки. Завдання початкового етапу досудового розслідування - найшвидше збирання інформації, необхідної та достатньої для визнання конкретної особи винною у вчиненні інкримінованого злочину та надійне її процесуальне закріплення.

Слідчі ситуації початкового етапу досудового розслідування є надбудовами комбінацій організаційних, криміналістичних, процесуальних, психологічних ознак, станів, дій і взаємодій над криміналістичними та слідчими ситуаціями початку кримінального провадження.

Слідчі ситуації початкового етапу досудового розслідування пропозиції, обіцянки або надання неправомірної вигоди мають враховувати такі характеристики: співвідношення у часі повідомлення про злочин і факту виконання об' єктивної сторони злочину, опис предмету злочину, фігурант провадження, організаційні ознаки та взаємодії всередині суб’єкту розслідування.

\section{Список використаних джерел:}

1. Авдєєва Г.К. Проблеми алгоритмізації слідчої діяльності. Актуальні проблеми держави $і$ права. 2008. URL: http://www.apdp.in.ua/v44/09.pdf.

2. Волобуєв А.Ф. Наукові основи комплексної методики розслідування корисливих злочинів у сфері підприємництва : автореф. дис. на здобуття наук. ступеня д-ра юрид. наук: 12.00.09. Х., 2002. 42 с.

3. Косарев С.Ю. История и теория криминалистических методик расследования преступлений. СПб : Юрид. центр Пресс, 2008. 495 с.

4. Лузгин И.М. Методологические проблемы расследования. М. : Юрид. лит., 1973. 216 с.

5. Тіщенко В.В. Теоретичні і практичні основи методики розслідування злочинів : монографія. Одеса : Фенікс, 2007. $260 \mathrm{c}$

6. Шеремет А.П. Криміналістика : навч. посіб. для студ. вищ. навч. закл. [2-ге вид.]. К. : Центр учбової літератури, 2009. $472 \mathrm{c}$.

\section{References:}

1. Avdeeva H.K. (2008). Problemy alhorytmizatsii slidchoi diialnosti [Problems of algorithmization of investigative activity]. Aktualni problemy derzhavy i prava [in Ukrainian].

2. Volobuiev A.F. (2002). Naukovi osnovy kompleksnoi metodyky rozsliduvannia koryslyvykh zlochyniv u sferi pidpryiemnytstva [Scientific bases of the complex technique of investigation of mercenary crimes in the sphere of business] : avtoref. dys. na zdobuttia nauk. stupenia d-ra yuryd. nauk: 12.00.09. Kh., 2002. 42 p. [in Ukrainian].

3. Kosarev S.Iu. (2008). Istoriia i teoriia kriminalisticheskikh metodik rassledovaniia prestuplenii [History and Theory of Forensic Crime Investigation Techniques]. SPb : Iurid. tcentr Press. 495 p. [in Russian].

4. Luzgin I.M. (1973). Metodologicheskie problemy rassledovaniia [Methodological problems of the investigation]. M. : Iurid. lit., 1973. 216 p. [in Russian].

5. Tishchenko V.V. (2007). Teoretychni i praktychni osnovy metodyky rozsliduvannia zlochyniv [Theoretical and practical bases of methods of investigation of crimes] : monohrafiia. Odesa : Feniks. 260 p. [in Ukrainian].

6. Sheremet A.P. (2009). Kryminalistyka [Криміналістика] : navch. posib. dlia stud. vyshch. navch. zakl. [2-he vyd.]. K. : Tsentr uchbovoi literatury. 472 p. [in Ukrainian]. 